\title{
Impact of Fiscal Decentralization on Non-Oil Economic Growth in a Resource- Rich Economy
}

\author{
Fakhri HASANOV ${ }^{*}$, Ceyhun MIKAYILOV ${ }^{* *}$, Sebuhi YUSIFOV ${ }^{* * *}$, Khatai ALIYEV ${ }^{* * * *}$
}

\begin{abstract}
The paper investigates effects of fiscal decentralization on non-oil sector development in case of Azerbaijan for the quarterly period of 2002 through 2013. Results obtained from Autoregressive Distributed Lag Bounds Testing approach show that share of local expenditures and revenues in total, measures of fiscal decentralization, have negative impact on non-oil GDP. This finding is consistent with other studies outcomes and can be considered adequate for the Azerbaijani economy due to the number of institutional constraints. The results of the research would provide a good insight for policy makers in implementing economic reforms to develop institutional aspects of decentralization and thus make it supportive for non-oil economic growth.
\end{abstract}

Keywords: Fiscal Decentralization, Economic development, Local government, Azerbaijan, Resource-Rich Economy

JEL Code Classification: H110, H720, H760, H770.

UDC: 336.1: 330.356

DOI: https://doi.org/10.17015/ejbe.2016.017.06

\footnotetext{
* Corresponding author. King Abdullah Petroleum Studies and Research Center, Saudi Arabia; Institute for Social Sciences and Humanities, Qafqaz University, Azerbaijan; Research Program on Forecasting, Economics Department, the George Washington University, USA; Institute of Control Systems, Azerbaijan National Academy of Sciences, Azerbaijan. E-mail: fhasanov@qu.edu.az

${ }^{* *}$ Institute for Social Sciences and Humanities, Qafqaz University \& Institute for Scientific Research on Economic Reforms, Azerbaijan. E-mail: cmikayilov@qu.edu.az

${ }^{* * *}$ Department of Public Administration, Azerbaijan Technology University \& Institute of Economics, Azerbaijan National Academy of Sciences, Azerbaijan. E-mail: s.yusifov@atu.edu.az

${ }_{* * * *}$ Institute for Social Sciences and Humanities, Qafqaz University \& Institute of Control Systems, Azerbaijan National Academy of Sciences, Azerbaijan, E-mail: xaliyev@qu.edu.az
} 


\section{Introduction}

Decentralization has been a hot topic for many years. Fiscal decentralization means granting governing bodies below central level (states, municipalities) the authority to raise tax revenues and take decisions on spending on their own initiative within a legal framework (Thiessen, 2004).

It is believed that fiscal decentralization process will bring significant consequences on resource allocation, public service delivery, equity, and macroeconomic stability (Oates, 1972; Tibout, 1956). In other words; theoretically, decentralization should have a positive impact on the economic development. There are many reasons explaining the rationale or benefits for decentralization, which significantly vary from country to country. In the case of developing countries, decentralization is mostly considered as a deepening process in democracy while in the transitional economies decentralization is seen as the solution in shifting from a command-based economy to a market-based economy.

The relationship between fiscal decentralization and economic growth has been analyzed in many researches. Empirical studies suggest that countries with strong degree of institutional development tend to have a positive relationship between fiscal decentralization and economic growth and those with large population size and weak institutions seem to have no positive relationship. The results are mixed for countries having small and medium size populations (Amagoh et al., 2012).

Traces of decentralization in Azerbaijan first appeared with the adoption of new Constitution in November 121995 (The Constitution of The Republic of Azerbaijan, 1995). The fourth section of the Constitution addresses the issue of local selfgovernment in particular detail. According to article 7 of the Law on Municipal Finance on the financial sources of municipalities, local self-governments have access to three main revenues sources: local tax (own-source), non-tax revenues (ceded revenues), and central government transfers. The own-source tax revenues include personal land tax, personal property tax, and mining tax, income tax paid by municipal enterprises (legal entities), local fees and duties, such as fees for advertising on public property, parking fees and hotel fees, other duties.

However, according to NGO AMD (2011), the existing situation does not provide efficient fiscal autonomy for localities and for improving their fiscal capacity. The studies show that only a few municipalities can benefit from the majority of these income sources in their budget formulation. NGO AMD further points out that the current revenue base assigned to municipalities in Azerbaijan is insufficient to adequately cover their expenditure needs (NGO AMD, 2011). They do not safeguard stable inflows to local budgets either. Local autonomy is confined to 1) some own source revenues which do not generate enough revenues and 2) minor intergovernmental transfers (Mikailov, 2007). 
Besides The Congress of Local and Regional Authorities of the Council of Europe has made two reports concerning the monitoring of local and regional democracy in Azerbaijan since 2003 and pointed out several problems including unclear division of tasks between levels of government; overlapping functions between local and central bodies; loopholes and contradiction in the legal framework between the municipal and sector laws; the weak financial potential of municipalities due to poor revenue assignment and low-level state transfers; ineffectiveness of the tax collection mechanisms available to municipalities (Council of Europe, 2012).

The question of how much the fiscal decentralization has contributed to non-oil sector growth in Azerbaijan is however, open to discussion. The issue is important as Azerbaijan ratified the European Charter on Local Self-Government in 2002 and committed itself to establishing effective local self-governance that conform to the requirements of the Charter. As a result, European Council urges Azerbaijan to accelerate fiscal decentralization process by allocating sustainable financial resources to municipalities proportional to their competences, and ensure that municipalities can freely manage their resources within the scope of their responsibilities. Therefore, if the process of fiscal decentralization directly or indirectly influences the economic growth and development, then the fiscal policymakers should consider this relationship in formulation and implementation of the policies.

This paper attempts to examine empirically what is the impact of the fiscal decentralization on the non-oil sector development. Our research questions are as follows: 1) Is there any long run relationships between fiscal decentralization and non-oil sector output 2) What is the role of fiscal decentralization in non-GDP sector growth in the short-run? and 3) If there is a long-run relationship, what is the speed of adjustment from the short-run deviations to the long-run equilibrium? In order to answer these questions, we apply co-integration and error correction modeling to the Azerbaijani data over the quarterly period of 20022013.We measure non-oil sector with non-oil GDP while fiscal decentralization is measured by shares of local government revenues and expenditures in overall government revenues and expenditures respectively.

The results from the Autoregressive Distributed Lag Bounds Testing (ARDLBT) approach indicate that the fiscal decentralization is negatively associated with the Non-oil sector development in Azerbaijan. The negative effect of fiscal decentralization is in line with the earlier findings of Ghafar et al. (2004), Philip et al. (2012), Davoodi et.al (1998), Zhang et al. (1998, 2001). This negative relationship is highly associated with inappropriate assignment of revenues among central and local governments, due to central government constraints on local government decisions. The results of the research would provide a good insight for policy makers in implementing economic reforms to develop non-oil economic growth. The outcomes reveal that there is a necessity to properly develop 
decentralization in Azerbaijan. Institutionally and financially developed local governments would better contribute to local economic development thus to overall non-oil economy.

The remainder of the paper is organized as follows. The literature review and theoretical framework are presented in Sections 2 and Section 3 respectively. Section 4 presents the data and Section 5 describes the methodology. Results from the empirical estimations are presented in Section 6. Section 7 discusses obtained empirical results and Section 8 covers conclusions and policy suggestions.

\section{Theoretical and Conceptual Framework}

This paper discusses the literature on fiscal decentralization and economic growth. It tests the theoretical argument that fiscal decentralization leads to economic growth in the case of Azerbaijan. The measurement of the degree of decentralization is based on the ratio of local government revenue and expenditure in total government revenue and expenditure, as they are considered as one of the most widely used indicators of decentralization. The higher this ratio, the more decentralized is the country. Number of scholars has considered fiscal decentralization as a way of promoting economic growth in the long run. The idea was in fact based on the views that under fiscal decentralization resources are better and more productively allocated leading to smaller public sector. This is possible because local decision makers are better informed about local priorities and better positioned for provision of local public goods, such as infrastructure and education (Oates, 1993). Another idea is that competition among different levels of government will promote lower tax rates and the efficient production of public goods due to revenue constraints (Brennan et al. 1980), or it leads to innovative approaches by local government in the production of public goods and services (Vazquez et al. 2003). Alfano (2009) analyzes decentralization of public policy within a complex framework.

However, there are number of other scholars raising concern about negative aspects of fiscal decentralization such as causing distortions in macroeconomic policy coordination and in implementation of stabilization policies (Tanzi, 1995, Ter-Minassian, 1997). Most empirical studies have focused on the share of local or sub-national government revenue or expenditure in consolidated national government revenue or expenditure as the measure of fiscal decentralization.

Most studies employ the endogenous growth model of Barro (1990), where the production function has multiple inputs including private and public spending (Davoodi et al., 1998, Zhang et al., 1998, Xie et al., 1999, Zhang et al., 2001, Akai et al., 2004, Sahin et al., 2014). They divide government expenditure into three levels of government (Davoodi et al., 1998) and analyze different decentralization shares regarding their consistency with growth maximization (Xie et al., 1999). Zhang et al. 
Impact of Fiscal Decentralization on Non-Oil Economic Growth in a Resource-Rich ...

(2001) also employ this approach and develop a model that links multiple sectors of government expenditure by multiple levels of government to economic growth.

Thus, Barro's growth model was major theoretical framework for the studies examining growth effects of fiscal decentralization. Barro proposes the following augmented production function:

$$
Y_{t}=f\left(L_{t}, K_{t}, G_{t}\right)
$$

Where, $Y$ is real GDP; $L$ and $K$ are the labor and real capital stock, respectively; G denotes government spending. $t$ indicates time.

Note that in the studies investigating fiscal decentralization's influence on economic growth, usually government spending is proxied by fiscal decentralization. Thus, equation (1) becomes:

$$
Y_{t}=f\left(L_{t}, K_{t}, F D_{t}\right)
$$

Here, FD is the fiscal decentralization.

In the empirical analysis, for the purpose of econometric estimation, (2) can be expressed as follows:

$$
y_{t}=\alpha+\beta l_{t}+\gamma k_{t}+\psi f d_{t}+\varepsilon_{t}
$$

Where, $y, I, k$ and $f d$ are the natural logarithm of $Y, L, K$ and FD respectively; $\alpha, \beta, \gamma$ and $\psi$ are the coefficients to be estimated econometrically; $\varepsilon$ is the error term.

\section{Literature Review}

Decentralization finds its traces in the pioneering works of Tibout (1956) and Oates (1972). In his work of 'A pure theory of local expenditures', Tibout stated that economic efficiency can be enhanced if the citizens are mobile so that they can resort themselves to the jurisdictions that best match their preferences. He argued that people will move from one jurisdiction to another jurisdiction to search for local services and taxes that maximize their utility. In other words, he argued that individuals 'vote with their feet' (Tiebout, 1956).

Oates (1972) followed this with his famous Decentralization Theorem, in which he argued that different communities have different demands for types and levels of public goods and services. He maintained that if there are different preferences for public goods between jurisdictions, the uniform provision of these goods by central government will lead to lower level of efficiency.

Another argument supporting fiscal decentralization was proposed by Brennan et al. (1980) in the 'Leviathan restraint hypothesis' which blames the governments for engaging in policies maximizing their revenues and size, by imposing higher taxes, borrowing or money printing. In the absence of intergovernmental competition, this in turn will lead to greater centralization creating a larger government size in 
the economy. The Leviathan effect can be minimized by limiting government's spending powers (balanced-budget requirement) or through fiscal decentralization. With fiscal decentralization attempt by one individual jurisdiction to excessively raise taxes will end up in a migration of local businesses and citizens to different jurisdictions with lower tax rates.

Fiscal decentralization means granting sub-national or local governments, (states, municipalities) the authority to raise their own tax revenues and freely dispose of them and make independent spending decisions within a legal framework (Thieben, 2004). The World Bank defines fiscal decentralization as the transfer of expenditure responsibilities and revenue assignments to lower levels of government' (World Bank, 2015).

It has also been held in theory that, fiscal decentralization may be conducive to economic growth. The basis economic argument for fiscal decentralization is, as mentioned above, it differentiates the provision of local outputs according to local preferences, tastes and conditions. It increases the effectiveness and efficiency of economic development, planning and implementation on the local level, thereby contributing to economic growth and development (Oates, 1972, Buchanan, 1980).

On the whole, there are many channels through which fiscal decentralization affects growth: heterogeneous channel, market-preserving channel, structural change channel, and innovation channel (Feld et al., 2009). These theoretical studies provide a basis to demonstrate that the effects of fiscal decentralization on economic growth may be positive depending on a number of institutional factors.

Traditionally decentralization was approached from the point of the view of efficiency gains that it brings to the provision of public goods and public sector, efficiency in resource allocation, increased responsiveness and accountability of the government, equitable provision of services to citizen indifferent jurisdictions, and preservation of macroeconomic stability. In the last decades, however, number of researchers started to question if the processes of fiscal decentralization can also promote the economic growth of a country. The idea is based on the assumption that transferring resources to sub national tiers of government and granting the greater financial autonomy will lead to allocative and production efficiency and, eventually, economic growth (Tiebout, 1956; Oates, 1972; Brennan et al., 1980). However, the empirical works on the economic effects of fiscal decentralization yielded ambiguous conclusions. It is not easy to empirically test the impact of decentralization on local and regional development as there are different measures for fiscal decentralization.

Empirical analyses made so far revealed very different associations between fiscal decentralization and economic growth. Some studies have found that there is a positive association between fiscal decentralization and economic growth (Huther et al., 1996; Lin et al., 2000, Akai et al., 2002, Limi, 2005). Others, in contrast, indicate that the relationship can be negative (e.g. Davoodi et al., 1998, Zhang et 
al., 1998, 2001). Yet, ThieSen (2003) uncovers a hump-shaped relationship between decentralization and development, indicating the potential existence of an optimal level of decentralization across countries. The link between decentralization and economic growth has varied from one region and one country to another and, in most cases, tends to be either neutral or insignificant (Davoodi et al. 1998, Woller et al. 1998, Rodrirguez-Pose et al. 2004).

While some empirical studies focused on analyzing the relationship between fiscal decentralization and economic growth through establishing comparisons with other countries - cross-country studies, the others limited themselves to verify the impact that multilevel government structures causes on the growth of a certain country - single-country studies. Of course, each has its own advantages and limitations. Among the most popular studies conducting cross-country analyses are Oates (1995), Phillips et al. (1997), Davoodi et al. (1998), Yilmaz (2000), Thieben (2000, 2003, 2005), limi (2005), Martínez et al. (2006), Bodman et al. (2006), Thornton (2007) and Baskaran et al. (2009). Single country analyses which is more of our interest in this study are Zang et al. (1998, 2001), Jin et al.(2005), Lin et al. (2000), Jin et al. (2005) and Qiaoet al.(2008), Xieet al.(1999), Akai et al. (2002) and Akai et al.(2007), Carrion et al.(2006), Pérez et al. (2006), Sole et al. (2006) and Esteban (2006), Desai et al.(2003), Moldogaziyev(2012).

Our country focus in this research is Azerbaijan, which is resource-rich emerging small open economy. Therefore, below we focus only those types of countries which are similar to Azerbaijan.

Samimi et al. (2010) analyzed the relationship between fiscal decentralization and economic growth in Iran, over the period of 2001-2007 across the 30 provinces of the country by using nonlinear fixed effect panel model. They found that there is a positive and significant nonlinear relationship between fiscal decentralization and economic growth of Iranian provinces.

Philip et al. (2012) analyzed the effects of fiscal decentralization on the growth of the Nigerian economy. In the Barro type growth model framework, they applied the Ordinary Least Squares Method to the Nigerian data over the period 19702009. They concluded that fiscal decentralization has negative impact on economic growth of Nigeria. Even when the period was divided into two sub-periods, i.e. 1970-1990 and 1991-2009, the negative relationship still exists.

Moreover, Ghafar et al. (2004), using data for different periods for Indonesia (19762000), Kazakhstan (1996-2000), Kyrgyzstan (1996-2000) and Malaysia (1973-2000) found that fiscal decentralization, measured as share of local government in total, is detrimental for growth in these countries.

Freinkman and Goldberg (2003) using the Three Stage Least Squares (3sls) estimate find that an increase in the tax retention (share of locally generated taxes that are left to the regional budget), has resulted in a significant positive effect on economic growth of most Russian regions for the period of 1996-1999. 
Sebastian et al. (2013) contributed to understanding the effects of fiscal decentralization on economic growth by hypothesizing that fiscally decentralized economies are more vulnerable to the growth curse of natural resources than fiscally centralized ones. They first employed Sachs et al. (1997) data set and then extended the data set up to 2008 together with the World Bank's Fiscal Decentralization Indicators and applied Computable General Equilibrium and econometric modeling framework. They concluded that results are robust to different measures of resource abundance and fiscal decentralization, as well as to different estimation techniques and time periods.

\section{Data}

Our data covers the quarterly period of 2002 through 2013. That is the only period which the data is available.

Non-oil GDP (GDPN) is a sum of the value added in million manat created in the economy excluding oil sector. The quarterly time series of the variable can be retrieved from the statistical bulletins of the Central Bank of Azerbaijan Republic (CBAR) (http://www.cbar.az/pages/publications-researches/statistic-bulletin/) or State Statistical Committee of Azerbaijan (SSCA).

Non-oil Employment (EN). It is employment in the economy measured in thousand persons less that in the oil sector. Note that non-oil employment is about $99 \%$ of the total. Quarterly time series of the variables are collected from the statistical bulletins of the State Statistical Committee of Azerbaijan (SSCA).

Capital Stock (CS). Since the capital stock in the quarterly frequency is not available, we constructed it using gross fixed capital formation in the framework of a perpetual inventory method. The perpetual inventory method can be expressed as below:

$$
K_{t}=I_{t}+(1-\sigma) K_{t-1}
$$

Where, $K$ and $I$ are capital accumulation and gross fixed capital formation respectively both in million manat. $\sigma$ denotes depreciation rate and $t$ indicates time. We use initial capital-output ratio to be 1:5 and constant depreciation rates of $5 \%$ in the construction of capital stock.

Note that, quarterly time series of the gross fixed capital formation are collected from the statistical bulletins of the State Statistical Committee of Azerbaijan (SSCA).

Total Government Revenues (TGR). Total government revenues consists of taxes, social contributions, grants receivable, and other revenue. Data is measured in million AZN and from bulletins of CBAR and Statistical Committee of the Republic of Azerbaijan. 
Impact of Fiscal Decentralization on Non-Oil Economic Growth in a Resource-Rich ...

Total Government Expenditure (TGE). Total expenditure consists of total expense and the net acquisition of nonfinancial assets. Data is measured in million AZN and from bulletins of CBAR and Statistical Committee of the Republic of Azerbaijan.

There is no clear agreement about how to best measure decentralization (Ebel et al., 2002). However, major of studies employ the ratios of local government revenues and expenditures in total government revenues and expenditures respectively (Martinez-Vazquez et al. 2005, Davoodi et al. 1998 among others).

Local Government Revenues (LGR) comprise of tax and non-tax revenues of Azerbaijani local governments including central government transfers. We obtained percentage shares of local government revenues in total from the State Statistical Committee of Azerbaijan. Then we simply calculate the local government revenues in million AZN multiplying the shares by the total government revenues (TGR).

Local Government Expenditure (LGE) consists of administrative expenses of local government, education costs, healthcare expenses, costs for establishing and developing of municipal housing and communal systems, road construction and development, municipal debt repayment, environmental protection costs and other expenses. We obtained percentage shares of local government expenditures in total from the State Statistical Committee of Azerbaijan. Then we simply calculate the local government expenditures in million AZN multiplying the shares by the total government revenues (TGE).

\section{Methodology}

This section discusses the empirical methodology employed in this research. First, we discuss the Augmented Dickey-Fuller (ADF hereafter) unit root tests. Then, we describe the ARDLBT cointegration method.

\subsection{Unit Root Test}

In empirical studies, examining the order of integration of the given variables has to be done by using Unit Root (UR hereafter) Test before conducting a cointegration analysis. For this purpose, the ADF (Dickey et al. 1981) test was employed. The ADF tests an existence of non-stationarity in a given time series. In other words, this test hypothesizes that a given time series is non-stationary.

For a time series variable expressed as $y$, the $t$-ratio on $b_{1}$ gives ADF statistics value from the regression:

$\Delta y_{t}=b_{0}+\psi$ trend $+b_{1} y_{t-1}+\sum_{i=1}^{k} \alpha_{i} \Delta y_{t-i}+\varepsilon_{t}$

In this equation, $b_{0}$ is a constant term; $\Delta$ and $k$ are first difference operator and number of lags respectively; trend is linear time trend; $\varepsilon_{t}$ is white noise residuals, and $i$ is the lag order.

This test has been broadly discussed in Dickey et al. (1981), Stock et al. (1993), 
Doldado et al. (1990), de Brower et al. (1998) and Enders (2010: 237-239) with advantages and disadvantages. However, we will not give a place to such detailed discussions here because of space limitation.

\subsection{Autoregressive Distributed Lag Bounds Testing (ARDLBT) Approach}

In Pesaran et al. (2001), one alternative approach to the cointegration was given as Autoregressive Distributed Lag (ARDLBT hereafter) method which we are going to employ in this research as a robustness check. This approach has several advantages in comparison with the alternative approaches such as applicability in small samples, easy application by employing OLS, there is not any endogeneity problem, simultaneously estimating long-run and short-run coefficients, applicability with both $\mathrm{I}(1)$ and $\mathrm{I}(0)$ series or combination of them (Pesaran et al. 2001, Oteng et al. 2006, Sulaiman et al. 2010). Because our number of observations is relatively small, this approach is more compatible to employ in our empirical analysis.

The approach is consisted of the following stages (Pesaran et al., 2001):

a) Construction of an Unrestricted ECM.

$$
\Delta y_{t}=c_{0}+\theta y_{t-1}+\theta_{y x x} x_{t-1}+\sum_{i=1}^{n} \omega_{i} \Delta y_{t-i}+\sum_{i=1}^{n} \varphi_{i} \Delta x_{t-i}+u_{t}
$$

In this equation, $y$ is the dependent, and $x$ is the explanatory variable where $u$ represents white noise errors. Drift coefficient was denoted by $c_{0}$ while $\theta_{i}$ shows long-run coefficients and $\omega_{i}$ and $\varphi_{i}$ stand for short-run coefficients.

In the ARDLBT application, one of the main issues is specify optimal lag length of the first differenced right-hand side variables correctly due to the sensitiveness of finding cointegrating relationship to correct lag order selection (Pesaran et al, 2001: 23). Following Pesaran et al. (2001), among others, by removing the serial autocorrelation of residuals, minimizing Akaike and Schwarz information criteria can be used to specify optimal lag length. For cases with small samples, existing literature suggests to refer to the Schwarz information criterion (Pesaran et al. 1999, Fatai et al. 2003).

b) After constructing an Unrestricted ECM, it can be tested if there is cointegrating relationship by using Wald-test (or the F-Test) on the $\theta_{i}$ coefficients.

Here, null hypothesis is no co-integration defined as: $\mathrm{H}_{0}: \theta_{1}=\theta_{2}=\theta_{3}=0$, where the alternative hypothesis is the opposite represented as: $\mathrm{H}_{1}: \theta_{1} \neq \theta_{2} \neq \theta_{3} \neq 0$.

If the value of computed F-statistic from the sample is greater than the highest level of the critical value corresponding to a given significance level, then we can reject the null hypothesis. In the same manner, we can fail to reject the null hypothesis if the sample value of F-statistic from is less than the lowest level of the critical level at a 
Impact of Fiscal Decentralization on Non-Oil Economic Growth in a Resource-Rich ...

certain level of significance. If the sample F-statistic value falls between lowest-andhighest bands of the critical value, then we may obtain inconclusive test results.

It is essential to mention that F-statistics in the ARDLBT cointegration test have nonstandard distribution. As a result, the conventional critical values of $\mathrm{F}$ - distribution are unusable. That is why the critical values of F-distribution should be employed which were calculated by Pesaran and Pesaran (see: Pesaran et al. 1997 or Pesaran et al., 2001).

c) As a result of the previous stage, it is acceptable to estimate/calculate the long-run coefficients if there is cointegrating relationship among the variables. Consider that calculation of these coefficients can be carried out on the basis of equation (5) by employing Bewley transformation (Bewley, 1979) or manually setting $c_{0}+\theta y_{t-1}+$ $\theta_{y x x} x_{t-1}$ to zero and solving this equation for $y$ as below:

$$
y=-\frac{c_{0}}{\theta}-\frac{\theta_{y x x}}{\theta} x+u
$$

d) The long-run residuals can be calculated on the basis of equation (4) and use it in the equation (3) by removing level variables and related coefficients:

$$
\Delta y_{t}=c_{0}+\sum_{i=1}^{n} \omega_{i} \Delta y_{t-i}+\sum_{i=1}^{n} \varphi_{i} \Delta x_{t-i}+\gamma e c m_{t-1}+u_{t}
$$

Where, $e c m_{t}=y_{t}-\frac{c_{0}}{\theta}-\frac{\theta_{y x x}}{\theta} x_{t}$

From the equation above, stability of the cointegration relationship can be inferred if the value of $\gamma$ is between -1 and zero, and statistically significant. This means that the short run deviations from the long-run equilibrium path are temporary and correct towards it.

\subsection{Small Sample Bias Correction in ARDLBT Approach}

There are different views on the validity of critical values of F-distribution for small and large size samples. Although the upper and lower critical values of F-distribution have been calculated by Pesaran and Pesaran (1997) by using sample sizes of 500 and 1000 as well as 20000 and 40000 replications respectively, Narayan (2005) questions the accurateness of these values for small sample sizes. Because they are calculated on the basis of large sample sizes, those critical values are not for small sample sizes (Narayan 2004, Narayan, 2005). To prove his claim, Narayan has made a comparison of the critical value calculated on 31 observations with the values in Pesaran et al. (2001) in the case of four regressors and at the $5 \%$ level of significance. His findings indicate that the critical value (3.49) from Pesaran and Pesaran (1997) is $18.3 \%$ less than the calculated critical value (4.13) by his own. So that, Narayan (2005) calculated new critical values of F-distribution for the small samples from 30 to 80 observations. Here, we are going to employ Narayan (2005) critical values in our ARDLBT cointegration test to handle a small sample issues. 


\section{Empirical Results}

In our case, we have three independent variables, and two different equations to be estimated: one with local government revenues variable, and second one with local government expenditures variable. Hence the equation (6) in this case is modified as follow:

$$
\begin{gathered}
\Delta y_{t}=c_{0}+\theta y_{t-1}+\theta_{y x} x_{t-1}+\theta_{y v} v_{t-1}+\theta_{y \vartheta} \vartheta_{t-1}+\sum_{i=1}^{n} \omega_{i} \Delta y_{t-i}+\sum_{i=1}^{n} \varphi_{i} \Delta x_{t-i} \\
+\sum_{i=1}^{n} \gamma_{i} \Delta v_{t-i}+\sum_{i=1}^{n} \pi_{i} \Delta \vartheta_{t-i}+u_{t} \\
\Delta y_{t}=c_{0}+\theta y_{t-1}+\theta_{y x} x_{t-1}+\theta_{y v} v_{t-1}+\theta_{y \vartheta} \xi_{t-1}+\sum_{i=1}^{n} \omega_{i} \Delta y_{t-i}+\sum_{i=1}^{n} \varphi_{i} \Delta x_{t-i} \\
+\sum_{i=1}^{n} \gamma_{i} \Delta v_{t-i}+\sum_{i=1}^{n} \pi_{i} \Delta \xi_{t-i}+u_{t}
\end{gathered}
$$

Where, $y_{t}$ - Non-oil GDP, $x_{t}$ - Non-oil Employment, $v_{t}$ - Capital Stock, $\vartheta_{t}-$ Local Government Revenues, $\xi_{t}$ - Local Government Expenditure variables.

First, in order to find out optimal lag length, which can provide both minimum value for the lag selection information criteria and non-correlated residuals, we estimate equations (9) and (10) with different lag lengths ranging from zero to four. Table 1 below recorded the results of optimal lag search exercise.

Table 1. Statistics for choosing optimal lag size for ARDL

\begin{tabular}{lcccc}
\hline \multicolumn{5}{l}{ Panel A: For equation (9) } \\
\hline $\mathrm{k}$ & $\mathrm{AIC}$ & $\mathrm{SBC}$ & $\chi_{S C}^{2}(1)$ & $\chi_{S C}^{2}(4)$ \\
\hline 0 & -5.59800 & -5.43420 & $6.6785[0.0098]$ & $18.754[0.0009]$ \\
$1^{*}$ & -17.3198 & -16.5006 & $1.1443[0.2847]$ & $4.8822[0.2996]$ \\
2 & -17.5499 & -16.0754 & $0.0419[0.8379]$ & $3.1864[0.5271]$ \\
3 & -17.9390 & -15.8091 & $17.603[0.0000]$ & $22.469[0.0002]$ \\
4 & -18.0422 & -15.2570 & $1.2133[0.2707]$ & $16.391[0.0025]$ \\
\hline \multicolumn{5}{c}{ Panel B: For Equation (10) } \\
\hline 0 & -5.1383 & -4.9745 & $2.9163[0.0877]$ & $19.196[0.0007]$ \\
$1^{*}$ & -16.5509 & -15.7317 & $2.3814[0.1228]$ & $5.7989[0.2147]$ \\
2 & -16.8493 & -15.3748 & $0.2771[0.5986]$ & $2.4369[0.6560]$ \\
3 & -17.3406 & -15.2108 & $13.460[0.0000]$ & $16.442[0.0025]$ \\
4 & -17.5625 & -14.7773 & $0.6262[0.4288]$ & $11.319[0.0232]$ \\
\hline
\end{tabular}

Note: $\mathrm{k}$ is a lag order while AIC and SBC are Akaike and Schwarz information criteria respectively. $\chi_{S C}^{2}(1)$ and $\chi_{S C}^{2}(4)$ are LM statistics for testing no residual serial correlation against lag orders 1 and 4 respectively. Probabilities are in brackets.

For the equations (9) and (10), as it can be seen the values above in the table AIC prefers four lags, while SBS suggests one lag. In small sample cases, it is suggestive to rely on the SBC (Pesaran \& Shin, 1999; Fatai, et. al, 2003). For both equations, the lag order of one provides serially uncorrelated residuals. This lag length is also 
Impact of Fiscal Decentralization on Non-Oil Economic Growth in a Resource-Rich ...

preferable in term of saving degree of freedom. Thus, we decided that the lag order of one is optimal for estimating equations (9) and (10). The estimation results and the residuals diagnostics test statistics are reported in Table 2 below.

Table 2. ARDL Specification and Residuals Diagnostics tests results

\begin{tabular}{|c|c|c|}
\hline \multicolumn{3}{|c|}{ Panel A: The estimated final ARDL Specification } \\
\hline \multirow[t]{2}{*}{ Regressor } & Equation (9) & Equation (10) \\
\hline & Coefficient (Standard Error) & Coefficient (Standard Error) \\
\hline $\operatorname{lngdpr}_{t-1}$ & $-0.9248(0.1822)$ & $-0.8756(0.1741)$ \\
\hline lcapsto $_{t-1}$ & $0.4628(0.2844)$ & $0.5212(0.2643)$ \\
\hline $\operatorname{lem} p_{t-1}$ & $4.9490(2.7067)$ & $4.0130(2.7197)$ \\
\hline Intercept & $-38.671(19.9422)$ & $-31.7794(23.7164)$ \\
\hline$\| l o c g r_{t-1}$ & $-0.1211(0.0847)$ & -- \\
\hline $\operatorname{llocge}_{t-1}$ & -- & $-0.1400(0.0712)$ \\
\hline$\Delta l n g d p r_{t-1}$ & $0.3328(0.1102)$ & $0.3308(0.1$ \\
\hline$\Delta /$ capsto $_{t}$ & $5.9346(1.0090)$ & $5.6643(0.9983)$ \\
\hline$\Delta$ lcapsto $_{t-1}$ & $-3.8464(1.2498)$ & $-3.3580(1.2714)$ \\
\hline$\Delta l e m p_{t}$ & $6.7941(3.0300)$ & $6.5065(2.9572)$ \\
\hline \multicolumn{3}{|c|}{ Panel B: Statistics and Residuals Diagnostics tests results } \\
\hline Equation (9) & $\begin{array}{l}\sigma=0.1085 ; \chi_{S C}^{2}(4)=4.1921[0.3806] \\
\chi_{\text {HETR }}^{2}(8)=7.6988[0.4634] ; \mathrm{JB}_{N}=3 .\end{array}$ & $\begin{array}{l}(2)=1.1612[0.5596] ; \\
0.1617] ; F_{F F}=0.8898[0.3522]\end{array}$ \\
\hline Equation (10) & $\begin{array}{l}\sigma=0.1059 ; \chi_{S C}^{2}(4)=5.2105[0.2664] \\
\chi_{\text {HETR }}^{2}(8)=4.5304[0.8063] ; \mathrm{JB}_{N}=3 .\end{array}$ & $\begin{array}{l}(2)=0.9266[0.6292] ; \\
0.1592] ; F_{F F}=1.6190[0.2119]\end{array}$ \\
\hline \multicolumn{3}{|c|}{$\begin{array}{l}\text { Notes: Dependent variable is } n g d p r_{t-1} ; \sigma \text { is standard error of regression; } \chi_{S C}^{2}, \chi_{A R C H}^{2} \text { and } \chi_{H E T R}^{2} \text { denote chi- } \\
\text { squared statistics to test the null hypotheses of no serial correlation, no autoregressive conditioned } \\
\text { heteroscedasticity, and no heteroscedasticity in the residuals; } J B_{N} \text { and } F_{F F} \text { indicate Jarque-Bera and } \\
\text { no functional form mis-specification statistics to test the null hypotheses of normal distribution and } \\
\text { no functional mis-specification respectively; Probabilities in brackets; Method: Least Squares; } \\
\text { Estimation period: 2003Q1-2013Q4. }\end{array}$} \\
\hline
\end{tabular}

According to Panel B, the estimated specifications do not have any problem with serial correlation, heteroskedasticity, non-normal distribution of the residuals as well as functional form. By following the methodological procedure given in sub-section 5.2 , we test for an existence of cointegrating relationship among the variables. Table 3 below tabulates the test results.

The table indicates that the sample F-statistic values are greater than the upper bound critical values of Narayan (2005) and Pesaran (2001) at the 1\% significance level for both models. Thus, based on the test results we reject the null hypothesis of no cointegration at the $1 \%$ significance level and thus, conclude that there is a longrun relationship among the variables.

Since we found cointegration among the variables, we can estimate the long-run coefficients (elasticities). The equations below express the long-run coefficients, which are normalized for Ingdpr in both estimated models:

$$
\begin{aligned}
& \operatorname{lngdpr}_{t}=-41.82+0.50 \text { lcapsto }+5.35 \text { lemp }_{t}-0.13 \text { llocgr }_{t}+u_{t} \\
& \text { lngdpr }_{t}=-36.30+0.60 \text { lcapsto }+4.58 \text { lemp }_{t}-0.16 \text { llocge }_{t}+u_{t}
\end{aligned}
$$


Fakhri HASANOV, Ceyhun MIKAYILOV, Sebuhi YUSIFOV \& Khatai ALIYEV

Table 3. F-statistic for testing an existence of cointegration in ARDLBT approach

\begin{tabular}{lcrrrr}
\hline & & \multicolumn{2}{c}{$\begin{array}{c}\text { Pesaran et al. (2001) } \\
\text { critical values }\end{array}$} & \multicolumn{2}{c}{$\begin{array}{c}\text { Narayan (2005) critical } \\
\text { values }\end{array}$} \\
\cline { 3 - 6 } The sample F-statistic & $\begin{array}{c}\text { Signi-ficance } \\
\text { level }\end{array}$ & $\begin{array}{c}\text { Low } \\
\text { bound }\end{array}$ & $\begin{array}{c}\text { Upper } \\
\text { bound }\end{array}$ & $\begin{array}{c}\text { Low } \\
\text { bound }\end{array}$ & $\begin{array}{c}\text { Upper } \\
\text { bound }\end{array}$ \\
\hline \multirow{2}{*}{ Equation (9): $F_{W}=5.9518$} & $1 \%$ & 3.65 & 4.66 & 4.270 & 5.412 \\
Equation (10): $F_{W}=6.5892$ & $5 \%$ & 2.79 & 3.67 & 3.078 & 4.022 \\
& $10 \%$ & 2.37 & 3.20 & 2.560 & 3.428 \\
\hline
\end{tabular}

Notes: $F_{W}$ is the F-value of testing the null hypothesis that $\theta_{i}=0$ in the Wald Test.Critical values are taken from the combination of 3 lagged level regressors, restricted intercept and no trend (See: Pesaran et al., 2001, pp. 300) and 44 observations (Narayan, 2005, pp. 1987).

Finally, we estimated the final ARDLBT-ECM specification by replacing lagged level regressors with the one-lagged error correction term, i.e. ect_ardlbt $t_{t-1}$. Here, ect_ardlbt denotes error correction term from the ARDLBT approach.

The table below tabulates the results:

Table 4. Final ARDL Specification and Residuals Diagnostics tests results

Panel A: The estimated final ARDL Specification

\begin{tabular}{lcc}
\hline Regressor & $\begin{array}{c}\text { Equation (9) } \\
\text { Coefficient (Standard Error) }\end{array}$ & $\begin{array}{c}\text { Equation (10) } \\
\text { Coefficient (Standard Error) }\end{array}$ \\
\hline ect_ardlbt $_{t-1}$ & $-0.8665(0.1772)$ & $-0.8260(0.1597)$ \\
$\Delta$ lngdpr $_{t}$ & $0.3074(0.1030)$ & $0.3068(0.0990)$ \\
slcapsto $_{t}$ & $6.3603(0.8394)$ & $6.0949(0.8388)$ \\
slcapsto $_{t-1}$ & $-4.2722(0.9971)$ & $-3.7501(1.0293)$ \\
slemp $_{t}$ & $-4.9016(11.6001)$ & $-4.6179(11.3120)$ \\
intercept $^{\text {intep }}$ & $0.0529(0.0448)$ & $0.0210(0.0452)$ \\
\hline
\end{tabular}

Panel B: Statistics and Residuals Diagnostics tests results

\begin{tabular}{ll}
\hline Equation (9): & $\sigma=0.1051 ; \chi_{\mathrm{SC}}^{2}(4)=3.4935[0.4789] ; \chi_{\mathrm{ARCH}}^{2}(2)=1.0228[0.5997] ;$ \\
& $\chi_{\mathrm{HETR}}^{2}(5)=3.9585[0.5554] ; \mathrm{JB}_{\mathrm{N}}=2.1452[0.3421] ; \mathrm{F}_{\mathrm{FF}}=0.6188[0.4368]$ \\
\hline Equation (10): & $\sigma=0.1027 ; \chi_{\mathrm{SC}}^{2}(4)=4.9040[0.2973] ; \chi_{\mathrm{ARCH}}^{2}(2)=0.5819[0.7476] ;$ \\
& $\chi_{\mathrm{HETR}}^{2}(5)=4.1704[0.5252] ; \mathrm{JB}_{\mathrm{N}}=2.3235[0.3129] ; \mathrm{F}_{\mathrm{FF}}=1.2153[0.2778]$ \\
\hline
\end{tabular}

Notes: Dependent variable is $\Delta l n g d p r_{t-1} ; \sigma$ is standard error of regression; $\chi_{S C}^{2}, \chi_{A R C H}^{2}$ and $\chi_{H E T R}^{2}$ denote chi-squared statistics to test the null hypotheses of no serial correlation, no autoregressive conditioned heteroscedasticity, and no heteroscedasticity in the residuals; $J B_{N}$ and $F_{F F}$ indicate Jarque-Bera and $F$ statistics to test the null hypotheses of normal distribution and no functional form mis-specification respectively; Probabilities in brackets; Estimation period: 2003Q1-2013Q4.

As shown in the table, the coefficients estimated in the final ARDL-ECM equations are statistically significant and the specification passes the tests for the residuals diagnostics and stability. Obtaining such kind of results is quite expected, because the final ARDL specification is just transformation of the ARDL specification given in Table 2. 
Impact of Fiscal Decentralization on Non-Oil Economic Growth in a Resource-Rich ...

\section{Interpretations of the Empirical Results}

This section interprets long- and short-run estimations results from the ARDLBT approach. According to the long-run equations (9) and (10), a $1 \%$ increase in the non-oil employment leads to $4.58-5.35 \%$ increase in the non-oil GDP. Although the elasticity are hugely large compared to what predicts the production function theory, they are with expected signs.

As it can be seen from the equations (11) and (12) and Table 2, the effect of capital stock on growth has been found to be positive, and statistically significant at the $12 \%$ significance level in equation (9) and at $6 \%$ in equation (10). As it seems from the longrun equations (9) and (10), a $1 \%$ increase in the capital stock leads to $0.5-0.6 \%$ increase in the non-oil GDP. It is obvious from the graph of the capital stock variable that, the variation of the variable during the period analyzed is insufficient, which causes to the lowering statistically significant effect of it on dependent variable. Note that the Augmented Dickey-Fuller test indicated that the variable is I(2), while PhillipPerron test says it is trend stationary process. But, visually it does not seem to be a trend stationary variable. For further investigation, we have used first differenced form of this variable in the level equations of the ARDLBT, Engel-Granger and Johansen approaches along with the other variables. But these estimations have not given adequate and significant results. We do not report the results here but they can be obtained under request.

According to the theory of the production function, labor and capital are expected to have positive impacts on growth. This theoretical expectation is supported by our findings. The findings are quite adequate to the Azerbaijani economy. Development of the non-oil sector is the main priority of the Azerbaijani government. It is particularly highlighted in country's strategic development concept, namely Azerbaijan 2020: Vision for Future. A number of programs and agencies are organized by the government in order to support growth in the sector. For example, National Fund for Entrepreneurship Support, Azerbaijan Export and Investment Promotion Foundation, Azerbaijan Investment Company are established for this purpose. Moreover, a number of government programs create attractive environment in the non-oil sector in terms of tax-free and subsidized activity. Even, the government invested some specific agricultural and non-oil industrial branches and built warehouses in the regions. Of course, all of these above-mentioned measures lead to increase capital and labor inputs of the non-oil sector, which consequently results higher economic growth.

The effect of local government revenues and local government expenditures on non-oil GDP has been found to be negative and statistically significant at the $17 \%$ and $6 \%$ significance levels respectively. These findings indicate that fiscal decentralization is harmful for the non-oil sector growth in Azerbaijan. As it seems from the long-run equations (9) and (10), a $1 \%$ increase in the local government revenues and local government expenditures leads to $0.13 \%$ and $0.16 \%$ decrease in the non-oil GDP 
respectively. Finding of negative impact of fiscal decentralization was also the case in Ghafar et al. (2004) for Indonesia, Kazakhstan, Kyrgyzstan and Malaysia; Philip et al. (2012) for Nigeria; Davoodi et al. (1998) for 46 countries, Zhang et al. (1998, 2001) for China. Davoodi et al. (1998) interpret the possible reasons of negative relationship between fiscal decentralization and economic growth as follow: (i) there is a lack of information about local government expenditure and its structure in terms of current and capital spending. Besides, it does not differentiate between welfare and social security spending and spending on infrastructure. (ii) Inappropriate assignment of revenues among different levels of government may cause lower growth. (iii) Due to central government constraints on local government revenue and expenditure decisions in developing countries, fiscal decentralization may not increase efficiency (iv) it is likely that local governments cannot meet local residents' needs and preferences. In fact, all of these explanations are equally true for Azerbaijan. Number of institutional and financial issues need to be tackled in order for local governments to have a positive effect on economic growth. These reforms encompass strengthening local government financial base through efficient revenue and expenditure assignment, loan easing, integrating local governments into regional development programs, enabling them become efficient local partners in developing local economic base. As emphasized by Feld et al. (2009), the negative impact of decentralization on economic growth can turn out a positive depending on a number of institutional factors related to the channels which fiscal decentralization affects economic growth. As an emerging economy that completed its transition from planned economy to market based one several years ago, Azerbaijan still has a number of problems in the institutional development of local governance to be tackled. Note that, NGO AMD (2011) states that current situation cannot ensure an efficient fiscal autonomy for the local governments.

Estimated speed of adjustment coefficient from the ARDLBT approach indicates that $83-87 \%$ of the whole short-run disequilibrium can be corrected towards the long-run equilibrium path during one quarter. It means that any shock related to fiscal decentralization will be completely adjusted during two quarters.

\section{Concluding Remarks}

Since its independence, one of the important reforms of the Azerbaijani government has been decentralization. Local governments were first introduced in the newly adopted Constitution on November 12 . The country ratified the European Charter on Local Governments in 2001 and committed itself to fulfillment of the Charter articles. Series of legislative reforms have been made with the aim of embedding the principle of local self-government in its domestic law and in order to guarantee its effective implementation. Transferring competences to local communities with adequate financial resources are in the core of reforms. 
However, the positive impact of the decentralization process on the country's economy is under question.

The purpose of this research was to examine the effect of fiscal decentralization on non-oil economic growth in Azerbaijan. Our measures for Fiscal Decentralization are local government revenue and expenditure for the period of 2002-2013, which is only available data for now. The empirical analysis shows that, both the local revenue and expenditure have negative influence on the non-oil economic growth.

We found statistically significant negative impact of fiscal decentralization on the non-oil real GDP in case of Azerbaijan, which supports earlier studies of Ghafar et al. (2004), Philip et al. (2012), Davoodi et al. (1998), Zhang et al. (1998, 2001). As Feld et al. (2009) emphasize, this impact can become positive depending on a number of institutional constraints related to the channels which fiscal decentralization affects economic growth. Besides, decentralization does not necessarily cause direct economic growth rates if the country is lacking appropriate legal systems, institutions and human capital. In fact, the effect might be reverse if decentralization's impact is detrimental on the country economy (Rodríguez-Pose et al. 2009). The same holds true for Azerbaijan. The lack of strong institutional capacity, firm and transparent rules for regulation of intergovernmental fiscal relations, weak financial autonomy and lower financial base of local governments are among reasons for low efficiency of local governments in Azerbaijan. As a result, local governments in Azerbaijan still have not proved to be real institutions dealing with local problems. This is first due to a parallel administration in the local level. Municipalities share most of their responsibilities with the local branches of central government where the second prevail most of the time. Their scope of responsibilities is not precise and limited to some social issues. Because of lacking sound financial base municipalities suffer from inadequacy of income as well. Despite the laws stipulate some sources of income for local governments; they have number of loopholes which prevent municipalities from benefiting these income sources.

On the other hand the existing structure of local government revenues shows that present revenues can cover only current expenditure and very little is spent on investment infrastructure. Insufficient investments and lack of capital stock in local level does not allow to make expansion in production and service areas and thereby to involve more workers. Consequently, both financial constraints and institutional problems mentioned above lead to negative impact of local government revenue and expenditure on economic growth. With the improvement of local governments, both institutionally and financially, it will be possible to diversify economy as local governments act as stimulator of regional development. Thus, through contributing to employment in the local level local governments can indirectly have positive effect on economic growth, which is seen from the research results. As the research reveals, capital stock has a positive effect on growth. Creation and diffusion of capital stock is possible through increase in investment 
spending by local governments, which is again related to the fiscal strength of local governments.

The existing lower level of local government revenue and expenditure ratio in total government revenue and expenditure reveals the necessity of strengthening local government finances. However, all of these are possible through series of institutional and financial reforms in local government system of Azerbaijan, which could be summarized s follows:

Local governments should be allocated sufficient financial funds in the form of local taxes, intergovernmental transfers and loan easing, adequate to fulfill their responsibilities;

Local governments should be assigned precise duties allowing them to implement investment projects in the regions which will further lead to capital stock accumulation and increased non-oil employment.

Local governments should be widely integrated into State Regional Development Programs aimed at diversification of the economy and be assigned specific tasks through specific grants in implementing regional projects. That will lead to more regional economic development thus to non-oil economic growth.

\section{Acknowledgments}

We deeply thank to the Editor of this journal and anonymous referees for their comments and suggestions. All remaining errors and omissions are our sole responsibility. Please, note that views expressed in this paper are those of the authors and do not necessarily represent the views of their affiliated institutions.

\section{References}

Alfano, M.R. (2009). Centralization and decentralization of public policy in a complex framework. Eurasian Journal of Business and Economics, 2(3), 15-34.

Akai, N. Nishimura, Y. \& Sakata, M. (2004).Fiscal Decentralization, Economic Growth and Economic Volatility - Theory and Evidence from State-level Cross-section Data for the United States. Discussion Paper Series no. 03-F-2, The Center for International Trade Studies, Faculty of Economics, Yokohama National University.

Akai, N. \& Sakata, M. (2002). Fiscal decentralization contributes to economic growth: evidence from state-level cross-section data for the United States. Journal of Urban Economics, 52, 93-108. http://dx.doi.org/10.1016/S0094-1190(02)00018-9

Akai, N. Yukihiro, N. \& Masayo, S. (2007). Complementarity, fiscal decentralization and economic growth. Economic of Governance, 8 (4), 339-362.

http://dx.doi.org/10.1007/s10101-007-0032-5

Amagoh, F. \& Amin, A. (2012). An examination of the impacts of fiscal decentralization on economic growth. International Journal of Business Administration, 3(6), 72-81. http://dx.doi.org/10.5430/ijba.v3n6p72 
Impact of Fiscal Decentralization on Non-Oil Economic Growth in a Resource-Rich ...

Barro, R. (1990). Government spending in a simple model of endogenous growth. Journal of Political Economy, 98, 103-125. http://dx.doi.org/10.1086/261726

Baskaran, T. \& Feld, L. (2009). Fiscal decentralization and economic growth in OECD countries: is there a relationship?Cesifo Working Paper Series, 2721.

Bewley, R. A. (1979). The Direct Estimation of the Equilibrium Response in a Linear Model. Economics Letters, 3 (4), 357-361. http://dx.doi.org/10.1016/0165-1765(79)90011-9

NGO AMD. (2011). Current situation of local self-governance in Azerbaijan: Review. Retrieved from http://www.alda-europe.eu/public/doc/276-Report_ingilis-2011_son.pdf, 07/02/2015.

Bodman, P. \& Ford, K. (2006). Fiscal decentralization and economic growth in the OECD. Macroeconomics Research Group, Discussion Papers 7, University of Queensland, Brisbane St. Lucia.

Brennan, G. \& Buchanan, J. (1980). The Power to Tax: Analytical Foundations of a Fiscal Constitution, Cambridge University Press, Cambridge.

Brennan, G. \& Buchanan, J. M. (1980).The Power to Tax-Analytical Foundation of a Fiscal Constitutions. Cambridge: Cambridge University Press.

Carrion, S. Luis, J. Espasa, M. \& Mora, T. (2006). Fiscal decentralization and economic growth in Spain. XIII Encuentro de Economía Pública, febrero, Barcelona.

Council of Europe. (2012). Resolution 345: local and regional democracy in Azerbaijan. Strasbourg, 16-18 October. Retrieved from https://wcd.coe.int/ViewDoc.jsp?id=1982467, $01 / 02 / 2015$.

Davoodi, H. \&Zou, H. (1998). Fiscal decentralization and economic growth: a cross-country study. Journal of Urban Economics, 43, 224-257.http://dx.doi.org/10.1006/juec.1997.2042

Desai, R., Freinkman, L., \& Goldberg, I. (2003). Fiscal federalism and regional growth, evidence from the Russian Federation in the 1990s. Policy Research Working Paper 3138, World Bank, Washington.http://dx.doi.org/10.1596/1813-9450-3138

Dickey, D., \& Fuller, W. (1981). likelihood ratio statistics for autoregressive time series with a unit root, Econometrica, 49, 1057-1072.http://dx.doi.org/10.2307/1912517

Doldado, J., Jenkinson, T., \& Sosvilla-Rivero, S. (1990). Cointegration and unit roots. Journal of Economic Surveys, 4, 249-273.http://dx.doi.org/10.1111/j.1467-6419.1990.tb00088.x

Ebel, R. D., \& Yilmaz, S. (2002). On the measurement and impact of fiscal decentralization. World Bank, Policy Research Working Paper, 2809.http://dx.doi.org/10.1596/1813-94502809.

Enders, W. (2010). Applied Econometrics Time Series, University of Alabama, Wiley Series in Probability and Statistics, 2nd 4th edition.

Esteban, S. (2006). La descentralización fiscal y el crecimien to económico. Aplicación a las Comunidades Autónomas de Régimen Común (1997-2001), Proquest Information and Learning Espa-ol, Madrid.

Fatai, K. Oxley, L. \& Scrimgeour, F.G. (2003). Modeling and forecasting the demand for electricity in New Zealand: a comparison of alternative approaches. The Energy Journal, 24, 75-102. http://dx.doi.org/10.5547/ISSN0195-6574-EJ-Vol24-No1-4

Feld, L., Thushyanthan B., \& Jan S. (2009). Fiscal federalism, decentralization and economic growth: a meta-analysis. Retrieved from http://www.unigraz.at/socialpolitik/papers/Feld.pdf, 07/02/2015. 
Ghafar, A. I., Hamzah, M. Z., \& Ritonga, J. T. (2004). Fiscal decentralization and economic growth: evidence from selected muslim countries. Journal Ekonomi Pembangunan, 9 (2), 109-116.

Limi, A. (2005) Decentralization and economic growth revisited: an empirical note. Journal of Urban Economics, 57 (3), 449-461. http://dx.doi.org/10.1016/j.jue.2004.12.007

Jin, H. Quian, Y. \& Weingast, B. (2005). Regional decentralization and fiscal incentives: federalism, Chinese style. Journal of Public Economics, 89, 9-10, 17191742.http://dx.doi.org/10.1016/j.jpubeco.2004.11.008

Jin, J., \& Zou, H. (2005). Fiscal decentralization, revenue and expenditure assignments, and growth in China. Journal of Asian Economic, 16, 1047-1064. http://dx.doi.org/10.1016/j.asieco.2005.10.006

Lin, J., \& Liu, Z. (2000). Fiscal decentralization and economic growth in China. Economic Development and Cultural Change, 49 (1), 1-23. http://dx.doi.org/10.1086/452488

Martínez-Vázquez, J., \& McNab, R. (2003). Fiscal decentralization, macrostability and growth. Papeles de Trabajo 11, SerieEcon'omica, Instituto de Estudios Fiscales.

Martínez-Vázquez, J., \& McNab, R. (2006). Governance and decentralization. In E. Gomez, G. Peterson, and P. Smoke (eds.). Decentralization in Asia and Latin America: towards a comparative interdisciplinary perspective, London: Edward Elgar.

Martínez, V. J., \& McNab, R. (2006). Fiscal decentralization, macrostability and growth. Hacienda Pública Espa-ola, 179, 25-50.

Mikailov, E. (2007). Intergovernmental fiscal transfers in Azerbaijan: role of tax-sharing in local government financing. Policy Paper, Retrieved from http://pdc.ceu.hu/archive/00003356/01/MIKAYILOV.pdf, 07/02/2015

Moldogaziyev, T. (2012). Fiscal Decentralization and Revenue Stability in the Kyrgyz Republic, 1993-2010. Eurasian Journal of Business and Economics, 5(9), 1-20.

Narayan, P. K. (2004). An econometric model of tourism demand and a computable general equilibrium analysis of the impact of tourism: the case of the Fiji islands. Unpublished PhD thesis, Department of Economics, Monash University, Melbourne, Australia

Narayan, P. K. (2005). The saving and investment nexus for China: evidence from cointegration tests. Applied Economics, 37, 1979-1990. http://dx.doi.org/10.1080/00036840500278103

Oates, W. E. (1972). Fiscal Federalism. Harcourt Brace Jovanovich. New York.

Oates, W. E. (1993). Fiscal decentralisation and economic development. National Tax Journal, 46 (2), 237-243.

Oates, W. E. (1995). Comment on 'Conflict and Dilemmas of Decentralisation' by Rudolf Hommes. In M. Bruni and B. Pleskovic (eds.) Annual World Bank Conference on Development Economics, 351-353.

Oteng, E. F., \& Frimpong, J. M. (2006). Bivariate causality analysis between FDI inflows and economic growth in Ghana. Munich Personal RePEc Archive, University of Munich, Germany.

Pérez, P., \& Cantarero, D. (2006). Descentralización fiscal y crecimien to económico en las region esespa-olas', Papeles de Trabajo 506, Instituto de Estudios Fiscales, Madrid.

Pesaran, H. M., \& Pesaran, B. (1997). Working with Microfit 4.0: Interactive Econometric Analysis, Oxford University Press, UK. 
Impact of Fiscal Decentralization on Non-Oil Economic Growth in a Resource-Rich ...

Pesaran, H. M., \& Shin, Y. (1999). An Autoregressive Distributed Lag Modeling Approach to Cointegration analysis, in S. Strom. Econometrics and Economic Theory in the 20th Century: The Ragnar Frisch Centennial Symposium, 371-413, Cambridge University Press, Cambridge, UK. http://dx.doi.org/10.1017/CCOL521633230.011

Pesaran, M. H., Shin, Y., \& Smith, R.J. (2001). Bound testing approaches to the analysis of level relationships. Journal of Applied Econometrics, 16, 289-326. http://dx.doi.org/10.1002/jae.616

Philip, A. T, \& Isah, S. (2012). An analysis of the effect of fiscal decentralisation on economic growth in Nigeria. International Journal of Humanities and Social Science, 2(8), 141-149.

Phillips, K., \& Woller, G. (1997).Fiscal decentralization and LDC economic growth: an empirical investigation. Journal of Development Studies, 34, 139-148.

Qiao, B., Martínez-Vázquez, J., \& Xu, Y. (2008).The tradeoff between growth and equity in decentralization policy: China's experience. Journal of Development Economic, 86, 112-128. http://dx.doi.org/10.1016/j.jdeveco.2007.05.002

Rodríguez-Pose, A., \& Bwire, A. (2004). The economic (in)efficiency of devolution. Environment and Planning A, 36 (11), 1907-1928.http://dx.doi.org/10.1068/a36228

Rodriguez-Pose, A., \& Krojier. A. (2009). Fiscal decentralization and economic growth in Central and Eastern Europe. Growth and change, 40 (3), 387417.http://dx.doi.org/10.1111/j.1468-2257.2009.00488.x

Sachs, J.D., \& Warner, A.M. (1997). Natural resource abundance and economic growth. Center for International Development and Harvard Institute for International Development. Harvard University Cambridge MA.

Sahin, O., Can, N., \& Demirbas, E. (2014). The effects of infrastructure determinants on Economic Growth: European Union sample. Eurasian Journal of Business and Economics, 7(13), 11-27.

Samimi, A. J., Lar, K. P. Haddad, G. K., \& Alizadeh, M. (2010). Fiscal decentralisation and economic growth in Iran. Australian Journal of Basic and Applied Sciences, 4(11), 5490-5495.

Sebastian, F. P., \& Raveh, O. (2013). The natural resource curse, fiscal decentralization, and agglomeration economies. OxCarre Working Papers 112, Oxford Centre for the Analysis of Resource Rich Economies, University of Oxford.

Solé-Ollé, A., \& Esteller, A. (2006). Decentralized provision of public inputs, government responsiveness to local. Retrieved from http://www.ual.es/congresos/econogres/docs /Haciendas\%20Territoriales/Haciendas\%20Territoriales\%201/Sole\%20Esteller.pdf,07/02/201 5.

Stock, J.H., \& Watson, M. (1993). A simple estimator of cointegrating vectors in higher order integrated systems. Econometrica, 61, 783-820. http://dx.doi.org/10.2307/2951763

Sulaiman, D. M., \& Muhammad, U. (2010). The bound testing approach for co-integration and causality between financial development and economic growth in case of Pakistan. European Journal of Social Sciences, 13, 525-531.

Tanzi, V. (1995), 'Corruption, government activities, and markets' in the economics of organized crime, edited by Gianluca Fiorentini and Sam Peltzman, Cambridge: Cambridge University Press. 
Ter-Minassian, T. (1997). Decentralizing government. Finance \& Development, September. Retrieved from https://www.imf.org/external/pubs/ft/fandd/1997/09/pdf/ter-mina.pdf, 07/02/2015.

Thieben, U. (2000). Fiscal federalism in Western European and selected other countries. Centralization or decentralization? What is better for economic growth?, Discusión Paper 224, Deutsches Institut für Wirtschaftsforschung, Berlin.

Thieben, U. (2003). Fiscal decentralization and economic growth in high income OECD countries. Fiscal Studies, 24 (3), 237-274.

Thieben, U. (2004). Modelling structural change of transition countries. Discussion paper 519, DIW Berlin.

Thornton, J. (2007). Fiscal decentralisation and economic growth reconsidered. Journal of Urban Economics, 61 (1), 64-70.http://dx.doi.org/10.1016/j.jue.2006.06.001

Tiebout, C. M. (1956). A pure theory of local expenditures. Journal of Political Economy, 64, 416-424.http://dx.doi.org/10.1086/257839

Thieben, U. (2005). Fiscal Decentralization and Economic Growth in Rich OECD Countries: Is there an Optimum? Economic Bulletin, 41 (5), 175-182.

World Bank (2015). Intergovernmental Fiscal Relations. Retrieved from http://www1.worldbank.org/publicsector/decentralization/fiscal.htm , 06/02/2015.

Xie, D. Zou, H. \& Davoodi, H. (1999). Fiscal decentralization and economic growth in the United States. Journal of Urban Economics, 45, 228-239. http://dx.doi.org/10.1006/juec.1998.2095

Yilmaz, S. (2000). The impact of fiscal decentralization on macroeconomic performance. National Tax Association, Proceeding of the 92, Annual Conference on Taxation, Atlanta, October, 24-26.

Zhang, T., \& Zou, H. (1998). Fiscal decentralization, public spending and economic growth in China. Journal of Public Economic, 67, 221-240. http://dx.doi.org/10.1016/S00472727(97)00057-1

Zhang, T., \& Zou, H. (2001). The growth impact of inter sectorial and intergovernmental allocation of public expenditure: with applications to China and India. China Economic Review, 12 (1), 58-81. http://dx.doi.org/10.1016/S1043-951X(01)00043-8 